\title{
ISLAM DAN MEDIA: KONTESTASI IDEOLOGI DAN EKONOMI POLITIK MEDIA ERA DEMOKRASI
}

\section{Pendahuluan}

Hubungan media dan Islam dalam konteks kontestasi diskursus Islam di Indonesia dicirikan oleh sebaran narasi yang plural dan tidak homogen. Berbeda dengan pandangan orientalistik yang selama ini dianggap sebagai rezime kebenaran oleh narasi dominan internasional, yang memandang artikulasi keberislaman salah satunya yang muncul di media sebagai narasi yang monolitik dan anti-modern, perkembangan media di dunia Islam khususnya di Indonesia seperti diutarakan oleh Janet Steele (2018) dalam Mediating Islam: Cosmopolitan Journalisms in Muslim Southeast Asia menunjukkan wajah media yang beragam baik ideologi maupun bagaimana masing-masing media menempatkan diri baik dalam hubungan dengan kuasa dan politik maupun pertanggungjawaban moral mereka secara profetik. Dalam konteks ekonomipolitik komunikasi, hubungan media dan Islam saat ini sangat berhubungan dengan dua perkembangan politik yang membentuk relasi sosial dan kekuasaan di Indonesia yakni politik populisme dan kuasa oligarki.

Di tengah perhatian publik terhadap munculnya politik populisme, analisis komunikasi politik terhadap fenomena politik ini adalah hal yang sangat penting namun sampai saat ini kurang diperhatikan. Urgensitas memahami dinamika politik populisme dari sudut pandang komunikasi politik khususnya di Indonesia terjadi mengingat tiga hal yakni: Pertama, sebagai sebuah kekuatan yang tengah tumbuh, politik populisme membutuhkan isu-isu kontroversial untuk membangun rantai pengikat yang mempersatukan keresahan kelompokkelompok sosial yang tergabung didalamnya. Oleh karena itu, produksi beritaberita yang berpotensi untuk menggerakkan kemarahan dari kelompok yang resah memiliki peran yang signifikan didalamnya. Kedua, kebangkitan populisme di Indonesia akhir-akhir ini berjalin kelindan dengan dengan kemunculan berita hoax, fake news yang tersebar di ruang-ruang media sosial. Dalam konteks ini menjadi penting untuk mengamati bagaimana produksi berita-berita tersebut berhubungan dengan modus-modus politik dari aliansi-aliansi sosial 
oligarkhi dalam pertarungan memperebutkan kuasa dan kemakmuran. Ketiga, pemahaman atas praktik komunikasi politik dalam pertarungan sosial arena ekonomi-politik di Indonesia sangat menentukan pembentukan subyek-subyek sosial yang terlibat dalam praktik politik saat ini.

Di tengah transformasi besar menuju masyarakat komunikasi lintas batas, tumbuh sebuah optimisme baru bahwa seiring dengan pesatnya perubahan dalam teknologi informasi membentuk generasi baru masyarakat yang terbuka terhadap perbedaan. Dalam asumsi optimistis tersebut, pergaulan lintas batas melalui media sosial dan akses kepada dunia internet melahirkan generasi baru yang memiliki akses komunikasi mancanegara yang melampaui kepompong teritorialnya. Dalam pandangan seperti ini lepaskan generasi milenial pada lalu lintas perbincangan kosmopolitan, maka secara otomatis mereka akan menghargai keragaman. Perkembangan terbaru di dunia internet dianggap membawa percepatan bagi pembentukan ruang publik demokratis yang bebas dominasi, karena memberi ruang artikulasi baru di luar media mainstream.

Pandangan optimistik tentang perkembangan teknologi informasi yang membantu pembentukan ruang publik demokratis ini melupakan bahwa kini dunia sedang mengarah pada penyempitan kesadaran menuju eksklusivisme golongan. Lalu lintas informasi dan ruang komunikasi lintas batas yang tersedia di dalam dunia maya tidak selalu identik dengan penghargaan terhadap keragaman. Melalui perbincangan di dunia maya, kita dapat menyaksikan berbagai bentuk dalih pembenaran terhadap aktivitas-aktivitas kekerasan yang dilakukan Negara Islam di Irak dan Suriah (NIIS). Demikian pula, melalui perbincangan dan informasi di media sosial, kita menyaksikan betapa krisis ekonomi neoliberal yang melanda dunia-termasuk di negara-negara majumengakibatkan tersebarnya sentimen populisme kanan yang antirealitas multikulturalisme.

Hal demikian juga terjadi di Indonesia, ketika perkembangan pertarungan politik di antara kekuatan oligarki berhasil menyeret sentimen eksklusivisme golongan dan radikalisme keagamaan sebagai alat untuk memuaskan perebutan kuasa dan kemakmuran. Dalam bingkai komunikasi politik yang tengah berlangsung dalam lalu lintas komunikasi di media sosial saat ini tidak dengan mudah disimpulkan sebagai terbentuknya wahana potensial bagi terbentuknya ruang-ruang publik yang bebas. Dalam pertarungan sosial diantara kekuatankekuatan sosial dominan saat ini, media sosial tidak kedap dari intervensi kekuatan elite tersebut melalui praktik yang disebut sebagai komodifikasi informasi. 
Seperti diutarakan oleh Vincent Mosco (2009) dalam the Political Economy of Communication bahwa komunikasi politik tidak hanya terkait dengan bagaimana penyajian informasi dan penggunaan medium komunikasi dalam hubungan antara negara dan masyarakat. Melampaui pandangan konvensional tersebut praktik komunikasi terhubung dengan ekonomi-politik terkait bagaimana arena komunikasi menjadi arena pembentukan relasi sosial dalam pertarungan kekuatan-kekuatan sosial untuk memperebutkan kuasa dan kemakmuran melalui proses komodifikasi informasi.

Dalam konteks komodifikasi, meminjam pemahaman Karl Marx dalam Das Kapital, Mosco (2009) menjelaskan bahwa dalam ruang komunikasi terjadi proses transformasi informasi dari nilai guna menuju informasi sebagai produk market yang memiliki nilai tukar untuk memperoleh keuntungan material dan kekuasaan. Dalam pemahaman seperti ini kita dapat memahami bagaimana lalu lintas padat informasi yang berkembang tidak saja di media-media mainstream namun juga di media sosial tidak hanya berguna sebagai sebagai wahana komunikasi sosial, namun juga dapat dimanfaatkan untuk memproduksi nilai tukar yang dimanfaatkan bagi kepentingan politik dalam momen-momen politik penting seperti Pilpres maupun Pilkada. Sebagai ilustrasi ketika seseorang menulis status di facebook maupun twitter dia tidak saja mendapatkan pengakuan sosial dalam bentuk like maupun comment, namun juga bertambah besar pengaruh seseorang di media sosial maka terdapat kesempatan yang luas bagi dirinya untuk membangun hubungan dengan kekuatan-kekuatan sosial dominan sehingga informasi dan pikiran yang ia tampilkan di media sosial memiliki nilai tukar dalam pertarungan sosial untuk memperoleh keuntungan material dalam relasi sosial tersebut.

Fenomena inilah yang dapat menjelaskan muali berkembangnya industri buzzerbuzzer yang bekerja sebagai spin doctor untuk menampilkan berita, informasi dan pandangan tertentu dalam cuitan di media sosial dan menyembunyikan perspektif lain sesuai dengan kepentingan dari kekuatan-kekuatan oligarkhi yang menjadi bagian dari klien maupun aliansi sosial mereka. Dalam bentuk yang lebih ekstrem hal ini juga menjelaskan munculnya industri-industri penyebaran berita hoax dan fake news seperti yang dilakukan oleh kelompok Saracen yang beroperasi semenjak Pemilihan Presiden 2014 sampai dengan Pemilihan Kepala Daerah Jakarta 2016 baru-baru lalu. Ditengah padatnya lalu lintas informasi dan pembelahan politik (minus ideologi) informasi yang memprovokasi kebencian dan berbasis berita palsu di masyarakat; penyebaran informasi tersebut seperti memuaskan keresahan sosial dari masyarakat kelas menengah dan miskin yang membutuhkan target dan kambing hitam dari pelampiasan kemarahan tersebut. 
Dalam konteks pertarungan politik saat ini, perkembangan media sosial dan informasi-informasi alternatif diluar media mainstream tidak memperlihatkan lahirnya kekuatan masyarakat sipil yang cerdas informasi yang dapat melakukan kontrol terhadap negara. Penyebaran hoax dan berita kebencian di media sosial justru berkembang menjadi kanker demokrasi, ketika penyebarannya dan kemampuannya untuk menarik publik dalam panggung politik justru menghancurkan fondasi dari tatanan dan nilai-nilai demokrasi itu sendiri. Dalam konteks ketika tubuh politik demokrasi Indonesia mengalami sakit kronis akibat dominasi kekuatan-kekuatan oligarkhi yang menjarah sumber daya publik dan institusi negara, penyebaran hoax dan informasi kebencian justu berpotensi menghancurkan tatanan masyarakat multikultural dan penguatan kebhinekaan, sementara bagi kekuatan aliansi sosial dominan tertentu informasi-informasi hoax dan penyebaran kebencian tersebut berperan sebagai senjata ampuh mereka untuk merebut kekuasaan, tanpa harus bertentangan dengan kepentingan ekonomi-politik mereka sendiri.

\section{Tentang Jurnal Ini}

Lebih jauh artikel-artikel dalam jurnal ini memperlihatkan bagaimana interaksi Islam dengan media ditempatkan dalam konteks dinamika ekonomi-politik yang berlangsung di Indonesia terutama pada era post-authoritarianisme. Artikel pertama oleh Arie Setyaningrum Pamungkas menguraikan tentang hubungan antara dakwah Islam dan media. Dakwah Islam dalam artikel ini bukan hanya ditujukan untuk menyampaikan pesan spiritual bagi pembentukan pribadi Muslim, melainkan juga ditujukan untuk suatu tujuan normatif, praktik moralitas publik yang didasari oleh interpretasi atas ajaran Islam tertentu. Perkembangan media telah memfasilitasi praktik dakwah, sejak masa kolonial dimana percetakan Al Qur'an bahkan ikut difasilitasi oleh pemerintah kolonial, hingga terbentuknya press Islam yang ikut mendorong munculnya nasionalisme sebagai bentuk resistensi, hingga bentuk-bentuk dakwah yang dimediasikan sehingga membentuk ranah publik Muslim. Keragaman medium dalam dakwah telah menciptakan ranah publik Muslim (Muslim public sphere) sehingga bukan hanya mampu menjadi basis terbentuknya konstituensi politik, bahkan pasar baru bagi identitas Muslim. Sengkarut antara kepentingan politis dan kapital ekonomi secara rentan mengubah muatan dakwah menjadi alat propaganda dan bahkan mampu menciptakan 'fandom' dimana komodifikasi Islam mengabdi pada logika pasar neoliberalisme.

Artikel kedua oleh Firly Annisa mengelaborasi tentang relasi antara media social dan public Islam dalam era Indonesia post-authoritarianisme. Apabila dihubungkan dengan tumbuhnya media sosial dan jaringan internet di 
Indonesia, micro celebrities menjadi komponen penting menghadirkan identitas Islam dalam budaya populer. Dengan mengelola wacana kesalehan melalui performativitas tubuh yang di unggah secara terus menerus di media sosial, publik Islam dapat terbentuk dengan berbagai tujuan seperti menggaet popularitas yang berujung pada keuntungan ekonomi dan popularitas. Penyebaran otoritas pengetahuan semakin terjadi dalam segmen-segmen kecil, yang justru sulit dikontrol dan justru dapat menjadi embrio radikalisme, fanatisme dan intoleransi karena hanya menghadirkan hitam putih agama yang sekali lagi miskin argumentasi dan kontemplasi.

Pada artikel ketiga Wahyudi Akmaliah menguraikan tentang kemunculan buzzers (penggaung) politik sekaligus influencer (subyek berpengaruh) di Indonesia pasca rejim Orde Baru dalam memproduksi informasi, mempengaruhi publik dan berdampak terhadap elektablitas tokoh politik yang mengajukan diri sebagai pemimpin dalam politik elektoral. Ada tiga pertanyaan yang diajukan; kekuatan struktur apa yang mempengaruhi perubahan sekaligus pergeseran arena politik dari mobilisasi massa turun ke jalan melalui keramaian kemudian menjadi ranah online? Bagaimana dampak perubahan lanskap tersebut seiring dengan kemunculan otoritas-otoritas baru dengan kehadiran penggaung politik sebagai sumber referensi pengetahuan yang menjadi preferensi pilihan warganet sekaligus mempengaruhi elektabilitas seorang calon dalam politik elektoral? Apa dampak ikutan yang muncul dalam ranah maya ini?

Artikel keempat, M Hilaly Basya menguraikan tentang bagaimana masyarakat Muslim Indonesia di Inggris menggunakan medsos. Sebagian besar dari mereka adalah dosen, aktifis, ulama muda, birokrat, dan lain-lain yang sedang menempuh pendidikan tingkat S2 atau S3. Hidup dalam nilai-nilai, norma, dan kebudayaan yang berkembang dalam masyarakat Inggris yang tentu saja memiliki perbedaan dengan di Indonesia menjadi konteks sosial yang menarik untuk dikaji. Fokus yang ingin dijelaskan dalam artikel ini adalah bagaimana pengaruh konteks sosial tersebut terhadap cara masyarakat Muslim Indonesia di Inggris menggunakan media sosial.

Artikel kelima ditulis oleh Subkhi Ridho mengobservasi berbagai wacana keberislaman yang hadir di media social khususnya di dalam tiga grup WhatsApp jamaah pengajian yaitu Pengajian Medina, Pengajian Safina, dan Pengajian al-Hijrah yang anggota-anggotanya berasal dari kelompok perempuan kelas menengah Muslim di kota Yogyakarta. Rata-rata anggota jamaah pengajian ini merupakan representasi dari perempuan kelas menengah Muslim yang kuat secara ekonomi dan kalangan terpelajar. Tulisan ini mengelaborasi pandangan mereka dan praktik mereka sebagai Muslim kota di media WhatssApp. Selain 
itu juga berusaha memahami konstelasi pandangan perempuan kelas menengah Muslim kota kaitannya dengan serangkaian demonstrasi yang menggunakan identitas Islam, seperti Aksi Bela Islam 411, dan 212.

Artikel keenam Yulianthi Muthmainah melihat bagaimana ideologi bias gender menyebar dalam ideologi yang menjadi pesan dalam berbagai film. Berangkat dari pemikiran Louis Althusser, tulisan ini melihat bagaima a media termasuk juga film, dikategorikan dalam kelompok institusi negara yang sangat efektif untuk menyebarluaskan ideologi tertentu pada masyarakat dari belbagai kalangan, layaknya yang terjadi dalam keluarga, disosialisasikan melalui rumahrumah ibadah ataupun lembaga pendidikan. Salah satu ideologi yang termuat dalam film adalah ideologi gender yang dikonstruksikan tidak hanya peran domestik perempuan tetapi, juga kontruksi identitas perempuan melalui simbol kecantikan wajah dan keindahan tubuh perempuan.

Sebagai penutup kami berharap agar keenam artikel tentang media dan Islam dalam analisis ekonomi-politik dalam jurnal ini dapat memberikan perluasan wawasan dan ketajaman analisis kritis berpijak pada analisis ekonomi-politik terkait bagaimana Islam dan keterkaitannya dengan media mempengaruhi dinamika social, politik dan ruang publik Indonesia terutama di era pascaotoritarianisme.

Akhirnya kepada para pembaca, kami berharap artikel-artikel yang terhimpun pada edisi jurnal kali ini dapat memberikan informasi dan pencerahan tentang tumbuhnya media sosial dan jaringan internet di Indonesia-yang menjadi faktor penting hadirnya identitas Islam dalam budaya populer-yang tak jarang menjadi alat penyebaran kebencian, informasi hoax yang berpotensi merusak tatanan sosial masyarakat. Isu-isu ini seharusnya menjadi gambaran akan pentingnya Pemerintah dan masyarakat luas agar dapat memaksimalkan kerja-kerja berbasis digital, sehingga era disruption yang sedang terjadi saat ini dapat dimaksimalkan oleh komponen masyarakat sipil dengan memperbanyak aksi-aksi kolaborasi, berbagi peran (sharing) dalam bidang sosial, ekonomi, pengentasan kemiskinan, ketertinggalan informasi, dan lainnya.

Selamat Membaca.

Airlangga Pribadi

Redaktur Ahli Jurnal MAARIF 